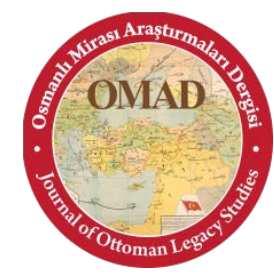

Osmanlı Mirası Araştırmaları Dergisi (OMAD), Cilt 3, Sayı 7, Kasım 2016, ss. 145-160.

Journal of Ottoman Legacy Studies (JOLS), Volume 3, Issue 7, November 2016, pp. 145-160.

ISSN 2148-5704

DOI Number: 10.17822/omad.2016.49

\title{
FRANCE'S POLICY TOWARDS THE GREEK INDEPENDENCE (1828-1830): A STUDY IN THE LIGHT OF UNPUBLISHED BRITISH DOCUMENTS
}

\author{
Fransa'nın Yunan Bağımsızlık Politikası (1828-1830): Yayımlanmamış İngiliz Belgeleri \\ Işı̆̆̆ında Bir Çalışma
}

\section{Yousef Hussein OMAR*}

\begin{abstract}
Relying on the unpublished British documents, this article examines the French policy on the Greek War of Independence. The article presents that despite its initial neutral stance, France teamed up with Britain to prevent a total Russian domination over Greece and openly supported Greek independence.
\end{abstract}

Key Words: Greek Revolution, Greek, Ottoman Empire, France, Eastern Question

Özet: Bu makale, Yunan bağımsızlık savaşı karşısında, Fransa'nın politikasını, İngiliz belgelerine dayanarak incelemektedir. Makale, Rusya'nın Yunanistan üstünde hakimiyet kurmak için izledği politikaya karşı, Fransa ve İngiltere'nin bir araya gelerek Yunan bağımsızlık mücadelesine destek verdiği tezini ileri sürmektedir.

Anahtar Kelimeler: Yunanistan Devrimi, Yunan, Osmanlı İmparatorluğu, Fransa, Doğu Sorunu

\section{Introduction}

Greece was part and parcel of the Ottoman Empire until the early nineteenth century. During this period, the heralds of Greek revolution emerged against the Ottoman Empire due to several factors: The development of the Greek society owing to the economic prosperity following Napoleon wars, the spread of European idea, especially the ideas of the French revolution, the reactions against the centrality of the Ottoman rule, the direct European intervention in the affairs of the Ottoman Empire. ${ }^{1}$

In Greece, several secret revolutionary movements, and political associations were established to call for the independence, and to endanger the integrity of the Ottoman Empire. Among these associations was Philikí Etaireía namely Friendly Brotherhood, which was established in Odessa located in southern Russia in 1814. The association called for liberating Greece and reviving the Byzantine Empire as well as capturing the Ottoman capital of Istanbul. $^{2}$ Philikí Etaireía association played a greater role in generalizing the call for revolution in Greece. It worked until 1821 for calling the Greek people to support and join it. So, its members reached at that time 20,000 members holding weapons for attaining independence. ${ }^{3}$

The Greek Alexander Ypsilantis (1792-1828), who worked as an officer in the Russian army, was the leader of Philikí Etaireía association in April, 1820. He worked for uniting the Christians in the Balkans to revolt against the Ottoman Empire, hoping that Russia or some

\footnotetext{
* (Assoc. Prof. Dr.) Al-Agsa University, Faculty of Arts and Human Sciences, History Department, Gaza/Palestine, email: yhomar73@yahoo.com

${ }^{1}$ Albert Boime, Social History of Modern Art (Chicago: University of Chicago, 1993), p. 194-6.

${ }^{2}$ Barbara Jelavich, History of the Balkans, Eighteenth and Nineteenth Centuries (Cambridge: Cambridge University Press, 1983), p. 204-5.

${ }^{3}$ Richard Clogg, A Concise History of Greece (Cambridge: Cambridge University Press, 1992), p. 31-5.
} 
European countries might intervene in their favor. Therefore, Ypsilantis crossed Pruth River on February 22, 1821 on the pretext of encouraging the Roman Christians, and he got the support of Russia. After two days, he issued an announcement calling on all Greeks and Christians to participate in revolting against the Ottoman Empire. ${ }^{4}$ But Ypsilantis did not abide by the orders coming from Russia. So, Russia decided to delete his name from the records of the Russian army and ordered him to leave the army. Ypsilantis aimed to make an alliance with Austria, but the latter did not prefer to encourage the minorities in Europe to be independent. Thus, calm prevailed afterwards in Greece. ${ }^{5}$

Yet, the revolution was still deep-rooted, where the Metropolitan Germanos (1771-1826) declared the revolution on March 25, $1821 .{ }^{6}$ Soon a large number of the Greeks joined him and achieved several victories over the Ottoman forced in more than one battle. ${ }^{7}$ This situation prompted the Ottoman Sultan Mahmud II (1808- 1839) to seek the assistance of Egyptian governor Muhammad Ali Pasha (1805-1849), ${ }^{8}$ who sent his son Ibrahim Pasha (1789-1848) to Methoni area on February 24, 1825. Ibrahim Pasha accomplished remarkable victories over the Greek insurgents, as a result, the Greeks mobilized the European public opinion to save the revolution, a group of leading poets and men of letters emerged, urging the European countries to intervene in the interest of the revolution. ${ }^{9}$

\section{Indications of the European Intervention in the Greek Question}

The European countries were divided regarding the Greek revolution, especially Russia during the reign of emperor Alexander I (1801-1825). As for Britain, it was more obvious in its attitude, especially after appointing George Canning (1822-1827) as a foreign minister. British government feared a unilateral Russian intervention against the Ottoman Empire, ${ }^{10}$ especially after the new Russian emperor Nicholas I (1825-1855) came to power. Therefore, Britain called on Russia to negotiate and consult for finding a solution to the Greek question. This situation resulted in signing the protocol of San Petersburg on April 4, 1826, which stipulated the intermediary of Russia and Britain between the Ottomans and the Greeks on the basis of full autonomy to Greeks under the Ottoman sovereignty. ${ }^{11}$

When Missolonghi, one of the strategic areas, fell to the hands of the Ottoman and Egyptian forces, this situation greatly affected the European public opinion. This led to renew negotiations among Britain, Russia and France and conclude London Treaty on July 6, 1827. This treaty stipulated the intervention between the Ottoman Empire and Greece to determine the Greek question on the basis of the independence of internal Greece under the Ottoman sovereignty. The treaty also stipulated that the two sides should stop fighting to pave the way for mediation. The countries agreed to offer mediation to the Ottoman government. If this offer was not accepted within a month, the countries would resort to force for implementing this demand. ${ }^{12}$

\footnotetext{
${ }^{4}$ Ibid, p. 32.

${ }^{5}$ Ibid, p. 32-3.

${ }^{6}$ Charles A. Frazee, The Orthodox Church and Independent Greece 1821-1852 (Cambridge: Cambridge University Press, 1969), p. 19.

${ }^{7}$ William St. Clair, That Greece Might Still Be Free, the Philhellenes in the War of Independence, (Cambridge: Open Book, 2008) p. 45.

${ }^{8}$ David Armine Howarth, The Greek Adventure (Collins: Atheneum, 1976), p. 18; Sayyid-Marsot and Afaf Lutfi, Egypt in the Reign of Muhammad Ali (Cambridge: Cambridge University Press, 1969), p. 206.

${ }^{9}$ Howarth, The Greek, p. 186-8.

${ }^{10}$ Leften Stavros Stavrianos, The Balkans Since 1453 (London: C. Hurst, 2000), p. 288-9.

${ }^{11}$ Jelavich. History, p. 226.

${ }^{12}$ Hertslet, Lewis. A Complete Collection of the Treaties and Conversations and Reciprocal Regulations, at Present Subsisting between Great Britain and Foreign Powers (London: Henry Butterworth, 1835), Vol. IV, p. 307-10; Schroeder, Paul W. The Transformation of European Politics 1763-1848 (Oxford: Oxford: University Press, 1994), p. 650-1; Seton-Watson, Robert William. Britain in Europe 1789-1914: A Survey of Foreign Policy (Cambridge:
} 
London Treaty was tantamount to salvage of the Greek revolution because it was concluded when the revolution was about to end. However, the Ottoman Empire and the Egyptian forces decided not to abide by the London Treaty. They sent their navies to strategic Navarino port. This situation was considered a challenge by the allies. So, Britain sent a navy of 12 ships under the command of the Admiral Edward Codrington (1770-1851), then came the French navy of 7 ships under the command of Admiral Henri de Rigny (1782-1835). The Russian navy of 8 ships arrived late under the command of the Admiral Lodewijk van Heyden (1772-1850), afterwards, the Russian navy joined the British and French navies under the general command of the Admiral Codrington, who besieged Navarino port and completely destroyed the Ottoman and Egyptian navies on October 20, 1827. The death toll of the Egyptians and the Ottomans was estimated 3 thousands, whereas the allies lost only 140 lives, and 300 injured. $^{13}$

\section{The Impact of the Russian Intervention on the French Attitude}

France was reluctant concerning the participation in any action related to the Greek question despite its absolute support to the Greek demand of independence. Yet, this reluctance had soon turned into a clear-cut decision to participate and join the other European countries. So, France participated in London treaty 1827, and sent its navy along with the Russian and British navies to the Greek waters. Thus, France became part and parcel of the European action supporting the independence of Greece. Since then, the French diplomacy had become active to coordinate with the other European powers. In addition, the European diplomacy, especially the British one had been invigorated to identify and coordinate the attitudes of the French government towards the Greek question. In this context, the British ambassador in Paris Leveson-Gower, $1^{\text {st }}$ Earl Granville, who was well- known as $1^{\text {st }}$ Earl Granville (1824-1828) sent to the British foreign minister John Ward, known as $1^{\text {st }}$ Earl of Dudley (April 30, 1827 - June 2, 1828) a message on January 11,1828, information him that the French foreign minister Pierre Louis Auguste Ferron, known as Count de La Ferronnays emphasized that cabinet reshuffle in France did not change the French policy regarding the issue related to the Ottoman Empire and Greece, Granville also spoke about the attitude of the Russian emperor Nicholas I concerning the treaties signed with regard to Greece and his view about achieving peace in this region of the world. ${ }^{14}$ Moreover, he spoke about delivering letters to La Ferronnays, stressing the necessity of working together in line with the British and French government, with regard to Greece. $^{15}$

At that time, the Russian memorandum was handed over to the French government by the Russian ambassador in Paris Carl Osipovich Pozzo di Borgo (February 17, 1821-January 5, 1835) concerning the current situation between Greece and the Ottoman Empire. The Russian emperor Nicholas I expressed his hope of agreeing with the European allies (France and England) for implementing the London treaty on July 6, 1827. He justified his decisions taken to mobilize his ground and naval forces against the Ottoman Empire. This produced a negative effect on France and Britain. The emperor confirmed that these decisions were not designed to expand at the expense of the Ottoman Empire. ${ }^{16}$

Granville emphasized in a letter to the British foreign minister Dudley on February 5, 1828, that La Ferronnays received correspondences from the government of Vienna under the command of the first advisor Prince Klemens Wenzel von Metternich (May 25, 1821-March 13, 1848) related to the existing affairs between Greece and the Ottoman Empire. Granville

Cambridge University Press, 1983), p. 117-8; Fry, Michael Graham - Goldstein, Erik- Langhorne, Richard. Guide to International Relations and Diplomacy (Great Britain: CPI Bath, 2002), p. 133-4.

${ }^{13}$ Jelavich. History, p. 226-7.

${ }^{14}$ F. O. 27-375, Granville to Dudley, Paris, 11 Jan. 1828.

${ }^{15}$ F. O. 27-375, Granville to Dudley, Paris, 18 Jan. 1828.

${ }^{16}$ F. O. 27-375, Granville to Dudley, Paris, 18 Jan. 1828. 
expressed his expectations that the remaining European countries would receive similar correspondences calling for both French and British governments to wait until the Ottoman government issued the right decision to put things in proper place. ${ }^{17}$

La Ferronnays replied to Vienna correspondences regarding Greece. He expressed his government's desire that war should not occur or take place between the European countries and the Ottoman Empire. He explained to Metternich the viewpoint of the French government that it adhered to London treaty on July 6, 1827. He also stressed the necessity that France, Austria and Britain should stand against any measures contrary to the treaty. ${ }^{18}$ Dudley confirmed to Granville on February 8, 1828 his support to the steps taken by the French government concerning the Greek question, calling for the continuation of unifying the political affairs between the two countries. This would positively affect the foreign policy, with reference to forming a close unity between France and Britain regarding the foreign affairs, particularly the Greek question. ${ }^{19}$

As far as the Greek question is concerned, the Ottoman sultan seemed to bet on the repeated changes in the French and British ministries. So, the European powers confirmed that the policy of the two countries regarding the Greek question was unchangeable. However, the opinions were directed towards calling on the Ottoman sultan to enjoy wisdom and work earnestly to stop his military forces in Greece, and what was called "aggression" acted on his own initiative and without the intervention of the countries. ${ }^{20}$ This situation didn't prevent the French foreign minister La Ferronnays from asserting to the Ottoman Empire that he depended on the sincerity of the country concerning the implementation of London treaty, stressing that the Russian emperor Nicholas I would not take any action inconsistent with the intentions of the allies about the Greek question. ${ }^{21}$

At the time, the correspondences indicated the Ottoman Empire issued its orders to the subjects of Britain, France and Russia for leaving Istanbul. Yet, Granville justified that by saying that the call of the Ottoman Empire was basically directed against Russia because of its hostile attitude towards the Islamic religion, "the calls were directed toward all Muslims by the Ottoman Empire to join under the banner of the Prophet Muhammad for defending their creed". ${ }^{22}$ This prompted to believe that the Ottoman Empire aimed at Islamizing the existing conflict during the revolution in Greece.

It was obvious that France showed great interest in the attitudes if the Ottoman government regarding the issue of implementing London on treaty for stopping wars and the results of capturing the Greek castles by the Turks. France condemned what was considered "attempts based on deception by the Ottoman Empire for delaying the implementation of London treaty items". ${ }^{23}$ Yet, the European countries accepted the proposal of the French government in introducing some amendments into London treaty items. ${ }^{24}$ At that time, the tone of the Ottoman government escalated against the allied European countries, especially Russia about the application of London treaty. Russia considered the tone escalation as an insult directed toward Russia by the Ottoman Empire. This escalation of situations between the Ottoman Empire and Russia pushed France and Britain to adopt new positions lest Russia should capture some Ottoman provinces. ${ }^{25}$ So, the France government officially decided not to ignore the results that might arise due to the invasion of the Ottoman Empire. It also declared its

\footnotetext{
${ }^{17}$ F. O. 27-375, Granville to Dudley, Paris, 5 Feb. 1828, No. 29.

${ }^{18}$ F. O. 27-375, Granville to Dudley, Paris, 8 Feb. 1828, No. 31.

${ }^{19}$ F. O. 27-374, Dudley to Granville, 8 Feb. 1828.

${ }^{20}$ F. O. 27-375, Granville to Dudley, Paris, 11 Feb. 1828.

${ }^{21}$ F. O. 27-375, Granville to Dudley, Paris, 18 Feb. 1828.

${ }^{22}$ F. O. 27-375, Granville to Dudley, Paris, 18 Feb. 1828, No. 41.

${ }^{23}$ F. O. 27-374, Dudley to Granville, 19 Feb. 1828, No. 24.

${ }^{24}$ F. O. 27-374, Dudley to Granville, 22 Feb. 1828.

${ }^{25}$ F. O. 27-375, Granville to Dudley, Paris, 22 Feb. 1828, No. 43.
} 
opposition in advance to what the Russian emperor Nicholas I intended to do regarding the Ottoman Empire. ${ }^{26}$

Granville met La Ferronnays in the royal palace "Tuileries" in Paris to hold discussions about the Greek question and the escalation between Russia and the Ottoman Empire as well as the negative effect that would produce if Russia proceeded with its forces to enter into the European provinces of the Ottoman Empire. ${ }^{27}$ This pushed France to give orders to its military battalions for moving towards the French port of Toulon to be sent to Greece. This was confirmed by the French newspapers, but the French foreign minister La Ferronnays denied his news, asserting that the movements of the French army aimed to prepare for implementing the decisions of London treaty only. ${ }^{28}$ Le Ferronnays newly expressed his hope of ending the Greek question without resorting to war. ${ }^{29}$

The outbreak of war between Russia and the Ottoman Empire was foreboding to both France and British. This situation prompted to declare the desire for meeting the representatives of the three powers of alliance (France, Britain and Russia) to look into the affairs related to the Ottoman Empire and Greece. Actually, the representatives of the allies met to prove that the three countries were insistent on their demands regarding Greece and the implementation of London treaty items. ${ }^{30}$ Therefore, France and Britain decided to advance their naval forces to besiege Greece, and threaten Ibrahim Pasha, the commander of the Egyptian forces if he did not withdraw his army. ${ }^{31}$ Both the French and British governments announced their agreement concerning the relation between the Ottoman Empire and Greece. The British government confirmed to the French government that "the friendly relations between the two countries were closer than before under the current circumstances". ${ }^{32}$

Dudley sent to Granville a letter on March $18^{\mathrm{h}}, 1828$ asserts his inability to identify the final decisions of British government concerning the Greek question because the British government was busy with the Portuguese questions. Yet, he expressed his strong desire that these decisions should be consistent with the desires of the French government for consolidating the ties between the two countries. ${ }^{33}$ So, both the governments of Britain and France expressed their opposition to the Russian desire to declare war against the Ottoman Empire. Both the governments announced their willingness to force the Egyptians to evacuate from Greece. ${ }^{34}$ Soon, the French government unilaterally expressed its concern over the latest attitudes of Russia regarding the Greek question. ${ }^{35}$

In any case, Dudley sent to Granville a letter on March 25, 1828, indicates the existence of some differences with France concerning some items London treaty. However, Granville mentioned at the same time that these differences could not at all affect the unity of opinion and understanding between the two countries and the implementation of the treaty that Russia or the sale of peace. ${ }^{36}$

The main concern of France regarding the Greek question was that Russia didn't take unilateral measures towards the existing conflict between Greece and the Ottoman Empire. This

\footnotetext{
${ }^{26}$ F. O. 27-375, Granville to Dudley, Paris, 29 Feb. 1828, No. 49; F. O. 27-376 Granville to Dudley, Paris, 10 March 1828; F. O. 27-374, Dudley to Granville, 14 March 1828, No. 37.

${ }^{27}$ F. O. 27-376, Granville to Dudley, Paris, 3 March 1828, No. 57; F. O. 27-376, Granville to Dudley, Paris, 21 March 1828.

${ }^{28}$ F. O. 27-376, Granville to Dudley, Paris, 7 March 1828, No. 61.

${ }^{29}$ F. O. 27-376, Granville to Dudley, Paris, 7 March 1828, No. 62.

${ }^{30}$ F. O. 27-375, Granville to Dudley, Paris, 25 Feb. 1828, No. 46.

${ }^{31}$ F. O. 27-376, Granville to Dudley, Paris, 14 March 1828.

${ }^{32}$ F. O. 27-376, Granville to Dudley, Paris, 17 March 1828, No. 74.

${ }^{33}$ F. O. 27-374, Dudley to Granville, 18 March 1828, No. 40; F. O. 27-374, Dudley to Granville, 21 March 1828.

${ }^{34}$ F. O. 27-376, Granville to Dudley, Paris, 22 March 1828, No. 82.

${ }^{35}$ F. O. 7-204, Cowley to Dudley, 22 March 1828, No. 39.

${ }^{36}$ F. O. 27-374, Dudley to Granville, 25 March 1828, No. 46.
} 
situation would eventually develop into declaring a war by Russian against the Ottoman Empire, especially that the Russian emperor expressed his desire to do so on many occasions, the last of which was his proposal to capture some Ottoman provinces. ${ }^{37}$ Perhaps this prompted France to take out the Russian justifications and excuses, and proposed to start with "military operations" for forcing the Ottoman Empire and the Egyptian forces to withdraw from Greece. ${ }^{38}$ This situation raised several questions and predictions, especially that France announced its opposition to any military action that would lead to war in the region several time. Granville sent to Dudley a letter on March 28, 1828, tells him of the possibility of declaring war by the Russian emperor against the Ottoman Empire. Granville spoke about the attitude of the Ottoman Empire if that happened. The latter considered that the violation of London treaty by Russia gave it the right to cancel this treaty. Granville also stressed the necessity of encouraging the sultan not to adhere to this opinion. He emphasized that entering Russia into war would harming the balance of powers in Europe in general. ${ }^{39}$

The escalation between Russia and the Ottoman Empire prompted Granville to exert maximum efforts to avoid war. So, he asked to meet the French foreign minister La Ferronnays, but they could not. The British and French governments deemed it necessary to identify the attitude of the allies soon regarding the Greek question despite the consensus of several European powers about the evacuation of the Egyptians and the Turks from Greece. ${ }^{40}$ This would push the French government newly to announce its previous commitments towards the Greek question and its cooperation with Britain. The British foreign Ministry Dudley stressed that the French government and the British government were committed concerning the unified action between the two governments over the Greek questions and the friendly relations between both countries. ${ }^{41}$

\section{France and the Policy of Military Intervention in Greece}

The French government expressed its desire to launch military operations against the Ottoman Empire in Greece for compelling it to withdraw and implement the decisions of London treaty. In this connection, La Ferronnays expressed his doubts over "the sincere desire" by the Ottoman Empire to abide by the decisions of the allies (France, Britain and Russia) regarding the stability of peace in Greece and the implementation of London treaty. ${ }^{42}$ So, Granville met La Ferronnays and informed him about the letters of Dudley concerning the reserved attitude of the British government towards the issue of evacuating the Ottoman armies from Greece by military operations proposed by France. ${ }^{43}$ The latter deemed it possible to launch military operations for compelling the Ottoman Empire and the Egyptian armies to evacuate from Greece. Seemingly, it began to be willing to do so. This matter called for an inquiry inside Britain. So, the British government sought information about the nature, purposes and preparations of the military naval powers in the French ports of the Mediterranean sea. ${ }^{44}$ This prompted La Ferronnays to declare that it would be possible to find a settlement to the attitude in Eastern Europe, namely Greece if there was a friendly attitude by Russia few months ago. La Ferronnays expressed his belief that time was too late after the Russian army had advanced against the Ottoman Empire. ${ }^{45}$

\footnotetext{
${ }^{37}$ F. O. 7-204, Cowley to Dudley, 27 March 1828, No. 44.

${ }^{38}$ F. O. 27-374, Dudley to Granville, 28 March 1828, No. 50.

${ }^{39}$ F. O. 27-376, Granville to Dudley, Paris, 28 March 1828, No. 89.

${ }^{40}$ F. O. 27-376, Granville to Dudley, Paris, 31 March 1828.

${ }^{41}$ F. O. 27-374, Dudley to Granville, 1 April 1828, No. 53.

${ }^{42}$ F. O. 27-376, Granville to Dudley, Paris, 4 April 1828, No. 98.

${ }^{43}$ F. O. 27-376.Granville to Dudley, Paris, 4 April 1828.

${ }^{44}$ F. O. 27-374, Dudley to Granville, 6 April 1828, No. 57.

${ }^{45}$ F. O. 27-376, Granville to Dudley, Paris, 7 April 1828, No. 98.
} 


\section{France and the Policy of Adhering to London Treaty}

It was obvious that the Russian tone against the Ottoman Empire escalated, thereby threatening the balance of powers and the political stability in Europe, and disunity among the allies. Under this explosive situation, and in order to stop the continuous escalation of Russia against the Ottoman Empire, both the governments of France and Britain were supposed to declare their commitment to London treaty, and the necessity of cooperation between the two countries in the foreign policy, particularly the Greek question. The two countries expressed their agreement about the bad results that would produce as a result of the Russian attempts to declare war against the Ottoman Empire. ${ }^{46}$

Therefore, London treaty had been renewed to be more obvious to the Ottoman Empire and the European powers, particularly Russia. The British government expressed its desire to get some remarks offered by the French government about the renewal of the treaty. ${ }^{47}$ The French government also declared its keenness to apply this treaty and achieve unity among the European powers. So, Dudley sent to Granville a letter on April 8, 1828, informing him that the British government had nothing but to be fully convinced of the good intentions of the French government. $^{48}$

\section{The Ottoman Empire and the Truce Proposal}

The Ottoman Empire submitted a truce plan at that time to stop war in Greece. Dudley expressed his view that the plan should be accepted, indicating that the Ottoman Empire which initiated the aggression -from his viewpoint-seemingly didn't intend to continue. The Ottoman Empire apparently had a desire to listen to the opinion calling for the stability of peace and security proposed by the allies. Dudley stressed that the call of the British government for lifting the siege and withdrawing the Ottoman Empire from Greece should continue until the end. ${ }^{49}$ However, some opinions called for not insisting on accepting this truce if Greece deemed it inconsistent with its own interests. ${ }^{50}$

The proposal put forward by the Ottoman Empire to hold a truce for stopping fighting in Greece didn't receive much attention in Europe, especially that some deemed it as an attempt to deviate from London treaty. Thus, the European diplomacy newly returned to explore the mechanisms for implementing London treaty. Granville expressed his opinion of the possibility of cooperating the Russian navy with the British and French navies for implementing London treaty. This prompted La Ferronnays to indicate that the French government was in agreement with the British government concerning Greece. There was no difference between them except for unimportant matters regarding the means and manners of implementing London treaty. La Ferronnays asserted that the two countries agreed to implement what the three countries confirmed -London Treaty- concerning peace in Greece. ${ }^{51}$ This was what Dudley confirmed to Granville on April 18, 1828 concerning the discussions with La Ferronnays. The talks focused on establishing cooperation between the French and British governments as well as maintaining friendship between them on sound lines. ${ }^{52}$

\section{France and Proposed Solutions to Greek Question}

La Ferronnays expressed his opinion about the possibility of participating Britain, France and Russia altogether in the Greek question, as well as sharing the Russian navy under the command of Heyden with both the British navy under the command of Admiral Codrington and

\footnotetext{
${ }^{46}$ F. O. 27-376, Granville to Dudley, Paris, 7 April 1828, No. 101.

${ }^{47}$ F. O. 27-376, Granville to Dudley, Paris, 10 April 1828, No. 104.

${ }^{48}$ F. O. 27-374, Dudley to Granville, 8 April 1828, No. 60.

${ }^{49}$ F. O. 27-374, Dudley to Granville, 8 April 1828.

${ }^{50}$ F. O. 27-376, Granville to Dudley, Paris, 11 April 1828, No. 108.

${ }^{51}$ F. O. 27-376, Granville to Dudley, Paris, 14 April 1828, No. 109.

${ }^{52}$ F. O. 27-374, Dudley to Granville, 18 April 1828.
} 
the French navy under the command of De Rigny in implementing London treaty. La Ferronnays called on the British government to express its opinion immediately concerning the problems and difficulties according to which British refused this cooperation. Granville spoke about the amounts of money estimated 20,000 sterling pounds, ${ }^{53}$ which were necessary for implementing the treaty. This high cost is one of the reasons for the reluctance of the British government in coordination with the European powers for implementing London treaty.

In this context, France proposed by its foreign minister La Ferronnays that every country of the allies (France, Britain and Russia) should pay 500,000 Francs monthly to the Greek government. ${ }^{54}$ It was obvious that Britain was not in favour of this proposal at all. So, La Ferronnays declared that the abstention of Britain from offering the proposed assistance to Greece didn't mean that France would do so. ${ }^{55}$ This compelled Dudley to delay his official reply concerning the remarks of La Ferronnays over this matter. However, the efforts were being devoted and directed towards the continuation of coordination and dialogue between both the British and French governments. ${ }^{56}$

In any case, there were more talks about the opposition of Britain to cooperate between both the British command and the French one with the Russian command for implementing London treaty for bringing about peace between Greece and the Ottoman Empire. Therefore, the orders were issued to both the British and French navies to separate from the Russian navy in the Mediterranean Sea. This situation compelled the Russian emperor to express his surprise about this step. Yet, the action was underway for implementing London treaty. ${ }^{57}$ So, the Russian government declared unwillingness to separate from its allies regarding the application of London treaty. ${ }^{58}$

However, the relations between Russia and Britain became tense day by day, because the Russian emperor was desirous of launching war against the Ottoman Empire. This prompted Britain to work and coordinate more with France. In this context, Granville newly praised the attitude of France regarding London treaty, and its prominent role in peace and security in Europe. ${ }^{59}$ Therefore, Granville had talks with La Ferronnays particularly about the attitude of the Russian government towards the implementation of London treaty. La Ferronnays reiterated the pressing need for offering financial assistance to the Greek government. He also re-affirmed the willingness of the French government to offer financial assistance and send a French commercial representative to Greece. ${ }^{60}$

\section{Russia and the Declaration of War against the Ottoman Empire}

Russia felt isolated after the separation of both the French and British navies. So, Russia submitted a proposal to France and Brittan to besiege Alexandria. But the French government indicated the grave harms that would cause to the French commerce in the city of Marseille as a result. The French government expressed its inability to share the allies and rather advised them not to take this step. ${ }^{61}$

It was obvious that Russia had various aims in Greece different from the remaining European countries concerning the support of the best elements and the creation of powerful areas it sought to achieve its historical ambitions to reach the warm waters of the Mediterranean Sea across Greece. It was clear and explicit that there was a growing rift between Russia and

\footnotetext{
${ }^{53}$ F. O. 27-376, Granville to Dudley, Paris, 18 April 1828, No. 113.

${ }^{54}$ F. O. 27-376, Granville to Dudley, Paris, 21 April 1828, No. 117.

${ }^{55}$ F. O. 27-376, Granville to Dudley, Paris, 21 April 1828, No. 118.

${ }^{56}$ F. O. 27-374, Dudley to Granville, 22 April 1828.

${ }^{57}$ F. O. 27-376, Granville to Dudley, Paris, 21 April 1828, No. 117.

${ }^{58}$ F. O. 27-374, Dudley to Granville, 25 April 1828, No. 72.

${ }^{59}$ F. O. 27-374, Dudley to Granville, 25 April 1828, No. 72.

${ }^{60}$ F. O. 27-376, Granville to Dudley, Paris, 25 April 1828, No. 123.

${ }^{61}$ F. O. 27-376, Granville to Dudley, Paris, 25 April 1828, No. 124.
} 
the rest European countries, especially France and Britain regarding the mechanism of implementing London treaty. These reasons made Russia declare war against the Ottoman Empire on April 26 $6^{\text {th }}, 1828 .^{62}$

The declaration of war by Russia against the Ottoman Empire and the differences among the European powers led to the meeting of the allies in London. La Ferronnays made a statement about the importance of avoiding any misunderstanding that might be considered dangerous to peace in Europe. He expressed his view that the question of Greek borders, its political relations with the Ottoman Empire should be discussed, and London treaty should be implemented in the conferences and the coming meetings. ${ }^{63}$ While the French government declared once again its desire to obtain consent from the British government for offering financial assistance to Greece, ${ }^{64}$ the British government, which was seemingly reluctant earlier, had declared its refusal to these demands unequivocally. ${ }^{65}$

The British government did not wish to make the relation with France tense due to its refusal to offer financial assistance to Greece and send French commercial representatives to it, especially that Russia started working alone against the Ottoman Empire through its declaration of war. Granville confirmed to Dudley on May 5, 1828 that he informed La Ferronnays about the desire of the British government to cooperate with the French government for solving the Greek question in line with the French viewpoints. However, the British government fell that the obstacles related to offer financial assistance to Greece might make the Greeks abstain from approving any measures taken by the allies. According to London treaty, Britain viewed that it was high time to appoint vice-consuls in Greece. Granville stressed that La Ferronnays was sorry for the decision of not offering any financial assistance to Greece, which was taken by the British government. Granville made it clear that the instructions issued to French vice-consul in Greece M. St. Denis, who was responsible for supervising the financial assistance offered by France to Greece by communicating continuously with the British foreign minister Dudley through Granville. Granville also was supposed to make contact with the Greek government to be aware of the demands of repairing military ships, and French belongings of possessions captured illegally. He would prepare a detailed report about London treaty. The allies wanted to obtain accurate information about the possessions owned by the Ottoman Empire. Greece would pay compensations according to the treaty as well as discuss the issue of the tribute paid by the Ottoman sultan. La Ferronnays thought that it was desirable to meet the ambassadors of three powers (France, Britain and Russia) in the Greek city of Curfo, and to send joint memorandum at once to the Ottoman Empire as a proof of their unity and agreement about the application of London treaty. This would have a great impact on the Ottoman government. ${ }^{66}$ Yet, the British government found it necessary to delay sending this memorandum to the Ottoman government. ${ }^{67}$

Granville sent to Dudley a letter on May 9, 1828, informing him that the French government was aware that the Ottoman sultan Mahmud II depended in this attitude regarding the Greek question on separating France and Britain from Russia. Granville stressed that the latest correspondences from Istanbul indicated that the sultan was the only one within the Ottoman Empire, who supported war against Russia. ${ }^{68}$

\footnotetext{
${ }^{62}$ David R. Stone, A Military History of Russia: From Ivan the Terrible to the War in Chechnya (USA: Greenwood Publishing, 2006), p.114; Seton-Watson. Britain, p. 128.

${ }^{63}$ F. O. 27-376, Granville to Dudley, Paris, 28 April 1828, No. 127.

${ }^{64}$ F. O. 27-374, Dudley to Granville, 29 April 1828.

${ }^{65}$ F. O. 27-376, Granville to Dudley, Paris, 5 May 1828, No. 135.

${ }^{66}$ F. O. 27-377, Granville to Dudley, Paris, 5 May 1828, No. 135.

${ }^{67}$ F. O. 27-374, Dudley to Granville, 9 May 1828, No. 85.

${ }^{68}$ F. O. 27-377, Granville to Dudley, Paris, 9 May 1828, No. 138.
} 
The French government expressed its regret repeatedly because the British government didn't agree to some French proposals for implementing London treaty. It emphasized that it didn't deny the validity of London treaty as a basis for bringing about peace in Greece. It didn't deny the right of the British government to receive the interpretation directly and openly from the government of Russia regarding the developments of the Greek question. At that time, the mobilizations of French forces were still existing nearby Toulon port, south east of France, hoping that Britain agreed to the measures related to the evacuation of the Ottoman and Egyptian forces from Greece provided that the Russian emperor declared to end the state of hostility towards the Ottoman Empire. At this time, the French government changed its attitudes, where the French foreign ministry headed by La Ferronnays stated that in case of the ongoing refusal of the British government to the proposal for offering financial aid to Greece, the French government didn't play its role in offering any financial aid to Greece. ${ }^{69}$

La Ferronnays stressed the necessity that the Russian emperor shouldn't forget that his allies depended on fulfilling his promises through carrying out actions agreed upon by the allies. However, France followed up the Russian military preparations on the ground, where La Ferronnays informed Granville of the detailed statement related to the preparation of the Russian forces which were due to be used in war and military operations. According to this information, some important Greek cities would be besieged, and the number of the Russian forces in war would be very large. There would be forces for achieving the siege and others for advancement. ${ }^{70}$ At the time, the Ottoman sultan still objected to implementing London treaty because it would result in dividing Greece, which was considered part and parcel of the properties of the Ottoman Empire. ${ }^{71}$

France and Britain was still skeptical of the Russian intentions. Granville sent to Dudley a letter on May 16, 1828 in which he said that he made contact with the French foreign minister La Ferronnays, and talked with him concerning the desire of Dudley for remaining the British ambassador in the Russian capital of San Petersburg, Sir William à Court well known as the Lord Heytesburg (1828-1832), besides to the Russian emperor during his war against the Ottoman Empire. La Ferronnays considered that it wasn't customary for the ambassador to remain beside the emperor, where the emperor wouldn't stay in the capital due to the circumstances of war, but he could invite the ambassador to attend. Yet La Ferronnays supported the existence of the allies representatives in the Russian army. He considered that it would be a real service to monitor the behaviors of Russia, especially the Russian emperor mentioned that if the representative of the Ottoman Empire, -who carried the peace initiative of his country-, intercepted his ship in the middle of Danube river, he would order to smash this ship. The Russian foreign minister sent Karl Robert Nesselrode (1814-1856) to the Ottoman Empire that the Russian military operations against the Ottoman Empire would stop only when the Russian forces reached the headquarters of the Ottoman sultan. ${ }^{72}$ Granville confirmed that the call of the Ottoman Empire for peace didn't stop the advancement of the Russian army, and the Russian emperor wasn't deceived by sending the Ottoman representative to understand with him for his previous knowledge that the aim was to gain time by the Ottoman Empire, not the desire for bringing about peace. ${ }^{73}$

Granville sent a letter to Dudley on May 19,1828 in which he said that he gave La Ferronnays correspondences dealing with the attitudes of British King George IV (January $29^{\text {th }}$, 1820-June $26^{\text {th }}$, 1830) regarding the French military mobilization in Toulon port and the financial aid to Greece. As for the French military mobilization in Toulon port, the British king

\footnotetext{
${ }^{69}$ F. O. 27-377, Granville to Dudley, Paris, 12 May 1828, No. 142.

${ }^{70}$ F. O. 27-377, Granville to Dudley, Paris, 12 May 1828, No. 145.

${ }^{71}$ F. O. 27-377, Granville to Dudley, Paris, 16 May 1828, No. 149.

${ }^{72}$ F. O. 27-377, Granville to Dudley, Paris, 16 May 1828, No. 148.

${ }^{73}$ F. O. 27-377, Granville to Dudley, Paris, 16 May 1828.
} 
deemed it necessary to coordinate with Britain in this connection. As for the financial aid proposed to be offered to Greece. The king asserted that Britain rejected to offer any financial aid to Greece due to the difference of public opinion in France rather than in Britain. Emphasis was placed on the importance of coordination between Britain and France for implementing London treaty. This situation required giving orders to commander of the British navy, Codrington and the commander of the French navy, De Rigny for coordination and cooperation altogether. Perhaps this situation prompted De Rigny to confirm strongly the instructions of his government -especially after the Russian declaration of war against the Ottoman Empire- about how to behave if the Russian military ships attacked the Ottoman ships or vice-versa. These instructions included how to evacuate Greece from the Ottoman and Egyptian forces and how to find a real truce, with the necessity of non- intervention of the French navy. ${ }^{74}$ Granville spoke to La Ferronnays about the memorandum offered by the Austrian government regarding the Greek question, which called for separating Greece totally from the Ottoman Empire, and establishing an independent Greek state. The memorandum could be offered by Austria to the French, British and Russian governments. In this context, La Ferronnays told Granville that if Russia and Britain agreed with the Austrian viewpoint, namely the separation of Greece totally from the Ottoman Empire and the establishment of an independent Greek state, France wouldn't oppose the allies, and take the necessary measures to implement this issue. ${ }^{75}$

With reference to the military efforts of the allies, La Ferronnays stressed to Granville that the instructions did not reach the commanders of the allies navies in the Mediterranean sea except the instructions that had been sent to the admiral De Rigny by French government. Yet, the correspondences involved that Ibrahim Pasha, the commander of the Egyptian forces had threatened to get revenge from the naval siege imposed on him by destroying the crop of Moura peninsulas. When La Ferronnays became aware of this information, he talked with Granville about the necessity of exerting maximum efforts to prevent this "tragedy". La Ferronnays also called on Granville to offer a proposal to Dudley. The essence of the proposal was that these instructions should be sent immediately by Britain and France to the commanders of the navies or the representatives of the two countries in Greece, asking them to inform Ibrahim Pasha that in case of carrying out these threats, he would lose the assistance of the allies by facilitating his withdrawal his army from Greece to Egypt. ${ }^{76}$ Granville sent to Dudley an elaborate letter on May $26^{\text {th }}, 1828$, in which he expressed the concern of both the French and British governments about some statements issued by the Russian emperor, that indicated an escalatory tone against the Ottoman Empire without previous coordination with France and Britain such as the right of Russia to sailing through the Ottoman straits, especially that the demands of Russia did not receive an approval from the Ottoman Empire. Surely, the declaration of hostility against the Ottoman Empire would continue until the implementation of London treaty. Thus it was necessary to observe that the continuation of war to achieve this objective, after the full conviction of the Russian complaints against the Ottoman Empire, would be really a deviation from the treaty. Therefore, the guarantees requested by Russia to navigate in Bosphorus strait required explanations to calm down the complaints and fears of the other allies. So, La Ferronnays suggested the necessity of continuous discussions and negotiations. He expressed his viewpoint that it was easy to get the approval of the sultan to give up some province rather than to agree to discuss with his subjects, namely the Greeks. La Ferronnays said that the independence of Greece in full was contrary to London treaty committed by France. ${ }^{77}$ For this reason, France reiterated its attitude towards the necessity of meetings in London for consulting and considering the latest affairs. ${ }^{78}$

\footnotetext{
${ }^{74}$ F. O. 27-377, Granville to Dudley, Paris, 19 May 1828, No. 152.

${ }^{75}$ F. O. 27-377, Granville to Dudley, Paris, 19 May 1828, No. 153.

${ }^{76}$ F. O. 27-377, Granville to Dudley, Paris, 23 May 1828, No. 156.

${ }^{77}$ F. O. 27-377, Granville to Dudley, Paris, 26 May 1828, No. 161

${ }^{78}$ F. O. 27-374, Aberdeen to Granville, 3 June 1828.
} 
In any case, a cabinet reshuffle had taken place in Britain. The British prime minister, Arthur Wellesley, known as $1^{\text {st }}$ Duke of Wellington (January $22^{\text {nd }}, 1828$-November $16^{\text {th }}, 1830$ ) appointed Earl of Aberdeen (June $2^{\text {nd }}, 1828$ - November $22^{\text {nd }}, 1830$ ) as a foreign minister instead of Dudley. However, a series of meetings went on between Granville and La Ferronnays. Granville told him about the instructions from London in which the British government would work towards the continuation of holding the conference in London to discuss the Greek question. This caused happiness to La Ferronnays and contributed to the agreement of opinions and sincere cooperation between the two countries. ${ }^{79}$

Granville newly interviewed La Ferronnays where they stressed the necessity of coordinating and establishing mutual trust between the two countries. Granville made it clear that the lack of information from Vienna indicated that the condition in Greece was turbulent. Yet, there were letters from Istanbul, describing the situation as quiet, but frustrating. ${ }^{80}$ The declaration of war by Russia against the Ottoman Empire still caused a state of commotion or unrest in Istanbul where the call for religious war spread in mosques despite the weakness and disorganization of the Ottoman army. ${ }^{81}$

The governments of France and Britain called for putting a dividing line between London treaty and the issue of the Russian war against the Ottoman Empire. The implementation of the treaty should be implemented regardless of the military operations carried out by Russia. However, the military operations by Russia had complicated the situation of the naval forces in France and Britain. ${ }^{82}$ This what La Ferronnays expressed when he said, "Russia put itself in a special situation regarding London treaty when it entered alone into war against the Ottoman Empire". La Ferronnays expressed the necessity of discussing the conditions stipulated by him personally for the return of both the ambassadors of France and Britain to Istanbul, ${ }^{83}$ after establishing the foundation for bringing peace to Greece a according to London treaty. This required a call for meeting the representatives of the allies once again in Istanbul to discuss the attitude of Russia in this connection. ${ }^{84}$

At that time, La Ferronnays received copies of the instructions sent to the navy commanders of the allies and delegates of the three countries in the Mediterranean Sea, which were agreed upon in London meetings. La Ferronnays expressed his complete satisfaction with the atmosphere of the meetings, especially the instructions regarding the borders of Greece. However, the news coming from Egypt indicated that if the force from the allies wasn't sent to Moura to evacuate the Egyptian forces, Muhammad Ali Pasha, the ruler of Egypt didn't issue his orders to his army for withdrawal. ${ }^{85}$

Aberdeen, the new British foreign minister, appointed once again Charles Stuart, known as $1^{\text {st }}$ Baron Stuart de Rothesay (1828-1830) as an ambassador to Britain in the French capital, Paris. La Ferronnays expressed his pleasure and greeting over the appointment of Rothesay, but the latter soon delivered news to La Ferronnays leading to the resentment of French government. The news indicated that the British government did not send any force to compel Ibrahim Pasha to give up Moura, but it did not object to sending a French force for this purpose. $^{86}$

\footnotetext{
${ }^{79}$ F. O. 27-377, Granville to Aberdeen, Paris, 6 June 1828.

${ }^{80}$ F. O. 27-377, Granville to Aberdeen, Paris, 6 June 1828, No. 169.

${ }^{81}$ F. O. 27-377, Granville to Aberdeen, Paris, 9 June 1828, No. 177.

${ }^{82}$ F. O. 27-374, Aberdeen to Granville, 17 June 1828, No. 10.

${ }^{83}$ F. O. 27-377, Granville to Aberdeen, Paris, 20 June 1828, No. 190.

${ }^{84}$ F. O. 27-377, Granville to Aberdeen, Paris, 23 June 1828, No. 194.

${ }^{85}$ F. O. 27-379, Granville to Aberdeen, Paris, 7 July 1828, No. 209.

${ }^{86}$ F. O. 27-379, Stuart de Rothesay to Aberdeen, Paris, 20 July 1828, No. 2.
} 


\section{The French Campaign on Greece}

La Ferronnays considered that he was under the influence of conditions that made France and Britain share in one thing. He made it clear that the cards of the game should be put on the table to overcome all the difficulties confronting the two countries. He also asked for reconsidering the issue of sending a joint force to intimidate Ibrahim Pasha and compel him to withdraw. In addition, he demanded to do the best to stabilize security in the east. He clarified that it was not possible to compel Ibrahim Pasha to evacuate from Moura. Ibrahim Pasha could be compelled to implement London treaty items through terrifying powers only. ${ }^{87}$ So, the French government reiterated its demand from Britain to approve of sending a French military campaign to exert pressure on Ibrahim Pasha for withdrawing from Moura. The British government responded positively to this demand, this situation caused satisfaction from the French government, which confirmed that its forces would withdraw immediately after achieving the purpose. ${ }^{88}$

Although France decided to send a military campaign to Greece, Rothesay, the new British ambassador in Paris, expressed his doubts that the Egyptian and Ottoman forces would give up the strongholds. He also expressed his belief that Ibrahim pasha wouldn't give up Moura due to the delay of supplies. Moreover, he doubted the solution of the problem immediately after the emergency of the forces of French campaign near the beaches of Greece. ${ }^{89}$ Yet, the French government continued in its military efforts, where it allocated 250,000 French franc for some military tasks. ${ }^{90}$ France re-emphasized its willingness to withdraw its forces immediately after signing the agreement relevant to the evacuation of Ibrahim Pasha forces. ${ }^{91}$

Therefore, France sent a number of military ships to participate in the military campaign. The sources expected that France would send a second campaign of knights and artillery men. ${ }^{92}$ Despite the apology of Britain to participate in the military campaign with France, it decided to send supplies to the French forces from its stores in Curfo. This obliged La Ferronnays to express his gratitude to the British government for this positive step in the relationship between the two countries. ${ }^{93}$

However, all the attention was directed towards Russia to end the state of tension with the Ottoman Empire. Finally, tension was conducive to war between the two countries. It wasn't possible for France to look down on the idea of destroying the Ottoman Empire, thereby losing the political balance in Europe. This resulted in causing unrest and instability. ${ }^{94}$

\section{The end of the Greek Crisis}

The plague emerged and the famine prevailed in Moura. Several questions were put forward about the effect of that crisis on the existence of the army. Ibrahim Pasha expressed his willingness to evacuate from Moura, ${ }^{95}$ but the French army affirmed that it would remain until the signing of the planned Alexandria agreement. The agreement stipulated the evacuation of the Egyptian forces from Moura. ${ }^{96}$ Actually, the agreement was concluded in Alexandria between the commander of the British navy, Codrington as a representative of the allies and

\footnotetext{
${ }^{87}$ F. O. 27-379, Stuart de Rothesay to Aberdeen, Paris, 21 July 1828, No. 1.

${ }^{88}$ F. O. 27-379, Stuart de Rothesay to Aberdeen, Paris, 25 July 1828, No. 6; F. O. 27-379, Stuart de Rothesay to Aberdeen, Paris, 15 Aug. 1828, No. 47.

${ }^{89}$ F. O. 27-379, Stuart de Rothesay to Aberdeen, Paris, 8 Aug. 1828, No. 33.

${ }^{90}$ F. O. 27-378, Aberdeen to Lord Stuart de Rothesay, 12 Aug. 1828, No. 16.

${ }^{91}$ F. O. 27-379, Stuart de Rothesay to Aberdeen, Paris, 15 Aug. 1828, No. 47.

${ }^{92}$ F. O. 27-379, Letter from Consul of Marseilles to D. R. Morier, 18 Aug. 1828.

${ }^{93}$ F. O. 27-379, Stuart de Rothesay to Aberdeen, Paris, 18 Aug. 1828, No. 19.

${ }^{94}$ F. O. 27-390, F.O. to Stuart, 21 Aug. 1829, No. 50.

${ }^{95}$ F. O. 27-379, Stuart de Rothesay to Aberdeen, Paris, 25 Aug. 1828.

${ }^{96}$ A. D. M. 1-469, Malcolm to Crocker, 2 Sep. 1828, No. 30.
} 
Muhammad Ali in isolation of the Ottoman Empire . The agreement stipulated the evacuation of the Egyptian forces from Moura. ${ }^{97}$ Thus, the Egyptian forces were expected to leave in August,1828 immediately after the arrival of he assigned ships. ${ }^{98}$

The Egyptian forces really began to depart from Moura on board of the ships described as so bad that they couldn't carry more than 5,000 soldiers with their horses, mules and supplies. Therefore, it was agreed that the soldiers should be transported in groups or batches. ${ }^{99}$ The first batch of the Egyptian forces of 5000 soldiers with their horses and equipment was to start while the second one was to wait until the arrival of ships. At the same time, the Greek subjects from men, women and children were checked to make sure that there was no slave with the Egyptians. ${ }^{100}$ Rothesay spoke about the circumstances leading Muhammad Ali to submit to the orders of all allies by withdrawing from Moura without obeying the Ottoman Empire. This situation made him take a hostile position against the sultan. However, the Egyptian withdrawal actually continued and eventually ended in the middle of October, $1828 .{ }^{101}$

As for the Ottoman Empire, it remained a lone in the face of the allies. The continuation of the Russian war against it was a great pressure leading eventually to conclude treaty of Adrianople on September $14^{\text {th }}$, 1829. According to the treaty, the Ottoman Empire agreed to the decisions of the countries mentioned in London treaty. So, it recognized the independence of Greek internally, and the sovereignty of the Ottoman Empire only nominally. Accordingly, the Ottoman Empire had withdrawn from it. ${ }^{102}$ Soon, the European powers agreed to give Greece full independence in $1830 .{ }^{103}$ The representatives of the great powers in Istanbul signed the treaty of Istanbul on July $21^{\text {st }}$, 1832. The treaty determined the borders of the new Greek realm. This situation was accepted by the Ottoman sultan and endorsed by the great powers within what was called London Protocol on August $30^{\text {th }}$, $1832 .{ }^{104}$

France, which adopted a hostile position against Muhammad Ali Pasha, tried to gain his favors politically after ending the question of Greek independence and its approval by the Ottoman Empire and the European countries. The French general consul in a Alexandria declared that Muhammad Ali could rely on the friendship and the support of the French government if necessary. ${ }^{105}$

In reality, Egypt became under the rule of Muhammad Ali pasha. It was characterized by a well-established friendship, especially during the rebellion and wars of Muhammad Ali Pasha against the Ottoman Empire from 1831 to 1840.

\section{Conclusion}

In this study, it is clear that the revolution of Greece imposed itself on the European countries, especially, that France feared its impact on the balance of powers and peace in Europe. This situation prevented it from taking a passive position towards the events and even prompted it to assume a favorable position towards the Greeks and their desire for independence. However, France didn't wish matters will escalate into European war or a

${ }^{97}$ A. D. M. 1-469, Malcolm to Crocker, 28 Aug. 1828, No. 287.

${ }^{98}$ A. D. M. 1-469, Malcolm to Crocker, 31 Aug. 1828, No. 288.

${ }^{99}$ A. D. M. 1-469, Malcolm to Crocker, 14 Sep. 1828, No. 291.

${ }^{100}$ A. D. M. 1-469, Malcolm to Crocker, 17 Sep. 1828.

${ }^{101}$ F. O. 27-396, Stuart de Rothesay to Aberdeen, Paris, 12 Oct. 1829.

${ }_{102}$ C. J. Bartlett, Peace, War and the European Powers 1814-1914 (London: MacMillan Press, 1969), p. 28.

103 John S. Koliopoulos - Thanos M. Veremis, Greece: The Modern Sequel: from 1831 to the Present (London: C. Hurst, 2004), p. 360; Erik Goldstein, Wars and Peace Treaties 1816-1991 (London: Routledge, 1992), p. 21; A. W Ward - G. P. Gooch, The Cambridge History of British Foreign Policy 1783-1919, Vol. 2 (Cambridge: Cambridge University Press, 1923), p. 103-5.

${ }^{104}$ Douglas Dakin, The Greek Struggle for Independence, 1821-1833 (California: University of California Press, 1973), p. 311; Roderick Beaton, - David Ricks, The Making of Modern Greece (UK: Ashgate Publishing, 2009), p. $1-3$.

${ }^{105}$ F. O. 27-390, F. O. to Stuart de Rothesay, 18 Dec. 1829, No. 88. 
bilateral war between Russia and the Ottoman Empire. This situation will increase the Russian competitive influence in the region at the expense of France.

The latter forced to establish a strong alliance with Britain. Both France and Britain had to form an alliance with Russia in accordance to what was called "the allies". They managed to restrain the traditional ambitions and desires of Russia. Yet, all the countries including France agreed to support the aspirations of Greece in attaining independence from the Ottoman Empire. For that matter, the independence was officially recognized and ratified in 1830.

\section{Bibliography}

\section{Unpublished British Documents}

Public Record Office (P.R.O), Foreign Office (F.O).

France, Series F.O. 27-375 (1828).

Austria, Series F.O. 7 (1828).

Admiralty Office (A. D. M), Series A. D. M. 1-469 (1828).

\section{Books}

Bartlett, C. J. Peace, War and the European Powers 1814-1914, London 1969.

Beaton, Roderick - Ricks, David. The Making of Modern Greece, UK 2009.

Boime, Albert. Social History of Modern Art, Chicago, 1993.

Clogg, Richard. A Concise History of Greece, Cambridge 1992.

Dakin, Douglas. The Greek Struggle for Independence, 1821-1833, California 1973.

Frazee, Charles A. The Orthodox Church and Independent Greece 1821-1852, Cambridge 1969.

Fry, Michael Graham - Goldstein, Erik- Langhorne, Richard. Guide to International Relations and Diplomacy, Great Britain 2002.

Goldstein, Erik. Wars and Peace Treaties 1816-1991, London 1992.

Hertslet, Lewis. A Complete Collection of the Treaties and Conversations and Reciprocal Regulations, at Present Subsisting between Great Britain and Foreign Powers, London 1835, Vol. IV.

Howarth, David Armine. The Greek Adventure, Collins 1976.

Jelavich, Barbara. History of the Balkans, Eighteenth and Nineteenth Centuries,Cambridge 1983.

Koliopoulos, John S - Veremis, Thanos M . Greece: The Modern Sequel: from 1831 to the Present, London 2004.

Sayyid-Marsot, Afaf Lutfi. Egypt in the Reign of Muhammad Ali, Cambridge 1969.

Schroeder, Paul W. The Transformation of European Politics 1763-1848, Oxford 1994.

Seton-Watson, Robert William. Britain in Europe 1789-1914: A Survey of Foreign Policy, Cambridge 1983.

St. Clair, William. That Greece Might still be Free, the Philhellenes in the War of Independence, Cambridge 2008.

Stavrianos, Leften Stavros. The Balkans Since 1453, London 2000. 
Stone, David R. A Military History of Russia: From Ivan the Terrible to the War in Chechnya, USA 2006.

Ward, A. W - Gooch, G. P. The Cambridge History of British Foreign Policy 1783-1919, Cambridge 1923, Vol. 2. 